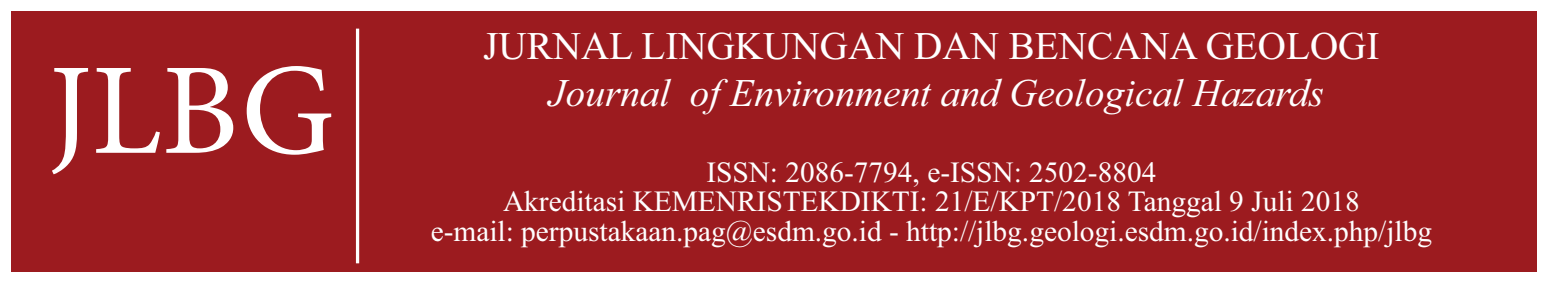

\title{
Analisis Potensi Likuefaksi di Daerah Cekungan Bandung Berdasarkan Data Standard Penetration Test (SPT)
}

\section{Analysis of Liquefaction Potential in Bandung Basin Area Based on Standard Penetration Test (SPT) Data}

\author{
Rima Putri Febriana ${ }^{1}$, Selly Feranie ${ }^{1}$, dan Adrin Tohari ${ }^{2}$ \\ ${ }^{1}$ Program Studi Fisika, FPMIPA, Universitas Pendidikan Indonesia \\ Jalan Dr. Setiabudi No.229, Isola, Kec. Sukasari, Kota Bandung - Indonesia \\ ${ }^{2}$ Pusat Penelitian Geoteknologi, Lembaga Ilmu Pengetahuan Indonesia \\ Jalan Sangkuriang, Cisitu, Dago, Kecamatan Coblong, Kota Bandung - Indonesia \\ e-mail: rimaputri.febriana@gmail.com \\ Naskah diterima 13 April 2019, selesai direvisi 04 April 2020, dan disetujui 29 April 2020
}

\begin{abstract}
ABSTRAK
Daerah Cekungan Bandung tersusun oleh endapan danau Bandung purba yang terdiri atas lapisan lempung yang belum mengalami konsolidasi dengan sisipan lapisan pasir sehingga rentan terhadap likuefaksi akibat gempa bumi. Makalah ini menyajikan analisis potensi likuefaksi di daerah Cekungan Bandung berdasarkan data Standard Penetration Test (SPT) dengan mempertimbangkan percepatan tanah puncak akibat gempa bumi bersumber dari Sesar Lembang $\left(M_{w} 6,5\right)$ dan akibat gempa bumi bersumber dari zona subduksi $\left(M_{w} 7,0\right)$. Hasil analisis menunjukkan bahwa potensi likuefaksi terjadi pada lapisan pasir di kedalaman yang bervariasi dan pengaruh percepatan tanah puncak terhadap potensi likuefaksi akibat gempa bumi bersumber dari Sesar Lembang lebih besar daripada gempa bumi bersumber dari zona subduksi. Mempertimbangkan ketebalan lapisan pasir dan kedalaman muka airtanah, penurunan tanah total akibat likuefaksi dapat mencapai $41 \mathrm{~cm}$ akibat gempa bumi bersumber dari Sesar Lembang dengan penurunan tanah total hingga $22 \mathrm{~cm}$ akibat gempa bumi bersumber dari zona subduksi.
\end{abstract}

Kata kunci: Cekungan Bandung, gempa bumi, likuefaksi, penurunan tanah, standard penetration test

\section{ABSTRACT}

The Bandung Basin area is composed of the old Bandung lake deposits consisting of unconsolidated clay layers with sand interlayers so that they are prone to earthquake-induced liquefactions. This paper presents an analysis of liquefaction potential in the Bandung Basin area based on the Standard Penetration Test (SPT) data under the pretext of the peak ground acceleration due to the Lembang Fault $\left(M_{w} 6.5\right)$ and the subduction earthquakes zone ( $M_{w}$ 7.0). The analysis shows that the liquefaction potential occurs in the sand layer at varying depths, and the effect of peak ground acceleration on the potential liquefaction due to Lembang Fault earthquakes is greater than the subduction earthquake. Considering the thickness of the sand layer and the depth of groundwater table, the total settlement due to liquefaction can reach $41 \mathrm{~cm}$ due to the earthquake of the Lembang Fault and the total settlement of $22 \mathrm{~cm}$ due to earthquakes in the subduction zone.

Keywords: Bandung Basin, earthquake, liquefaction, settlement, standard penetration test

\section{PENDAHULUAN}

Gempa bumi dapat menyebabkan kerusakan pada struktur lapisan tanah. Salah satu jenis bahaya ikutan akibat gempa bumi adalah likue- faksi, yaitu peristiwa lapisan tanah pasir lepas mengalami kehilangan kuat geser secara drastis karena meningkatnya tekanan air pori sebagai akibat terjadinya tegangan siklik dalam geta- 
ran tanah yang sangat cepat dan dalam waktu sesaat (Idriss dan Boulanger, 2008). Menurut Stewart dan Knox (1995), fenomena likuefaksi dapat terjadi hingga kedalaman lebih dari $30 \mathrm{~m}$. Sedangkan menurut Youd drr. (1979), potensi likuefaksi dapat terjadi pada wilayah yang tersusun oleh lapisan pasir lepas dengan kedalaman muka airtanah hingga 15,2 m.

Potensi likuefaksi dapat dianalisis menggunakan metode standard penetration test (SPT) atau uji penetrasi standar. Data SPT ini telah banyak digunakan untuk mengungkap tahanan tanah berpasir terhadap likuefaksi karena SPT menghasilkan sampel tanah yang representatif untuk menentukan sifat-sifat indeksnya melalui uji laboratorium (Tokimatsu dan Yoshimi, 1983). Mase (2018) melakukan studi keandalan metode analisis likuefaksi menggunakan SPT akibat gempa bumi tanggal 12 September 2007 dengan kekuatan $\mathrm{M}_{\mathrm{w}}$ 8,6 di wilayah pesisir Kota Bengkulu. Hasil penelitiannya menunjukkan bahwa metode Idriss dan Boulanger (2008) merupakan metode yang paling mendekati prediksi dan kejadian likuefaksi di lapangan.

Di sisi lain, daerah Cekungan Bandung merupakan wilayah yang memiliki tingkat kerentanan tinggi terhadap gempa bumi. Kemudian Sesar Lembang adalah salah satu sumber gempa bumi potensial yang terletak sekitar $10 \mathrm{~km}$ di sebelah Utara Kota Bandung. Sesar Lembang menunjukkan bukti geomorfik yang jelas tentang aktivitas terkini dan telah lama dianggap aktif dengan laju pergerakan 1,95 - 3,45 mm per tahun. Dengan panjang $29 \mathrm{~km}$, Sesar Lembang dapat menghasilkan gempa bumi $\mathrm{M}_{\mathrm{w}} 6,5-7,0$ dengan waktu pengulangan 170-670 tahun (Daryono drr., 2019). Berdasarkan penelitian sebelumnya, gempa bumi dengan intensitas gempa 3,3 SR yang terjadi pada Agustus 2011 di daerah Cisarua, Lembang, Kabupaten Bandung Barat diakibatkan oleh pergerakan Sesar Lembang (Sulaeman dan Hidayati, 2011). Selain akibat aktivitas pergerakan Sesar Lembang, gempa bumi besar yang terjadi akibat aktivitas pergerakan lempeng pada zona subduksi di selatan Pulau Jawa juga dapat berdampak terhadap daerah Cekungan Bandung. Gempa bumi
$\left(M_{w}\right.$ 7) yang terjadi pada 2 September 2009 di selatan Pulau Jawa (USGS, 2009) juga dirasakan di daerah Cekungan Bandung.

Berdasarkan kondisi geologi, daerah dataran Cekungan Bandung terbentuk oleh endapan danau purba yang terdiri atas material lepas berukuran lempung, lanau, pasir, dan kerikil yang bersifat tufaan dan mengandung sisipan breksi sehingga sangat rentan terhadap getaran seismik (Handayani drr., 2009). Berdasarkan data pemboran, Hamandi drr. (2006) menyimpulkan keberadaan akuifer dangkal pada kedalaman 0-35 $\mathrm{m}$ di bawah permukaan tanah di daerah Cekungan Bandung. Sementara itu, berdasarkan data kedudukan muka airtanah dan peta sebaran muka airtanah terdapat beberapa wilayah di daerah Cekungan Bandung yang memiliki muka airtanah yang dangkal dengan kedalaman $<10$ m (Hutasoit, 2009).

Dengan mempertimbangkan kondisi geologi, kegempaan dan hidrogeologi, maka pengetahuan tentang potensi likuefaksi di daerah Cekungan Bandung sangat penting untuk mendukung upaya pengurangan risiko bencana gempa bumi di daerah ini. Makalah ini menyajikan analisis potensi likuefaksi di daerah Cekungan Bandung dengan menggunakan metode SPT dengan sasaran untuk (1) mengetahui kedalaman lapisan tanah yang mengalami likuefaksi dan penurunan tanah akibat likuefaksi dan (2) mengevaluasi faktor-faktor yang mempengaruhi potensi likuefaksi di daerah ini. Dengan mempertimbangkan pembangunan bangunan tinggi dengan pondasi dalam di daerah Cekungan Bandung, evaluasi potensi likuefaksi dilakukan hingga kedalaman $30 \mathrm{~m}$ di setiap lokasi.

\section{METODE PENELITIAN}

Untuk analisis potensi likuefaksi, SPT dilakukan dengan interval 1,5 m hingga $2 \mathrm{~m}$ di 9 titik pemboran teknik hingga kedalaman $30 \mathrm{~m}$ yang tersebar di daerah Cekungan Bandung (Tabel 1 dan Gambar 1). Contoh tanah yang diperoleh dari setiap uji penetrasi tersebut dianalisis untuk menentukan jenis tanah dan persentase partikel halus 
Analisis Potensi Likuefaksi di Daerah Cekungan Bandung Berdasarkan Data Standard Penetration Test (SPT)

Tabel 1. Lokasi pemboran teknik di daerah Cekungan Bandung

\begin{tabular}{|llccc|}
\hline \multirow{2}{*}{ Kode Bor } & \multicolumn{1}{c}{ Lokasi } & \multicolumn{2}{c|}{ Koordinat } & \multicolumn{2}{c}{ Kedalaman muka airtanah } \\
\cline { 3 - 4 } & & ${ }^{\circ}$ LS & ${ }^{\circ}$ BT \\
\hline BH-01 & Desa Tegalluar, Kec. Bojongsoang & $-6,982$ & 107,701 & 1,0 \\
BH-02 & Desa Rancakesumba, Kec. Solokan Jeruk & $-7,011$ & 107,725 & 3,0 \\
BH-03 & Desa Rancakesumba, Kec. Solokan Jeruk & $-7,027$ & 107,743 & 3,5 \\
BH-04 & Kelurahan Rancaekek Kesumba, Kec. Rancaekek & $-6,975$ & 107,757 & 15,0 \\
BH-05 & Desa Bojongemas, Kec. Solokan Jeruk & $-6,997$ & 107,732 & 7,0 \\
BH-06 & Desa Sumbersari, Kec. Ciparay & $-6,996$ & 107,694 & 1,0 \\
BH-07 & GBA, Desa Cipalago, Kec. Bojongsoang & $-6,982$ & 107,650 & 15,5 \\
BH-08 & Baleendah Permai, Desa Baleendah, Kec. Baleendah & $-7,007$ & 107,638 & 1,5 \\
BH-09 & Desa Padamukti, Kec. Solokan Jeruk & $-7,012$ & 107,769 & 10,2 \\
\hline
\end{tabular}

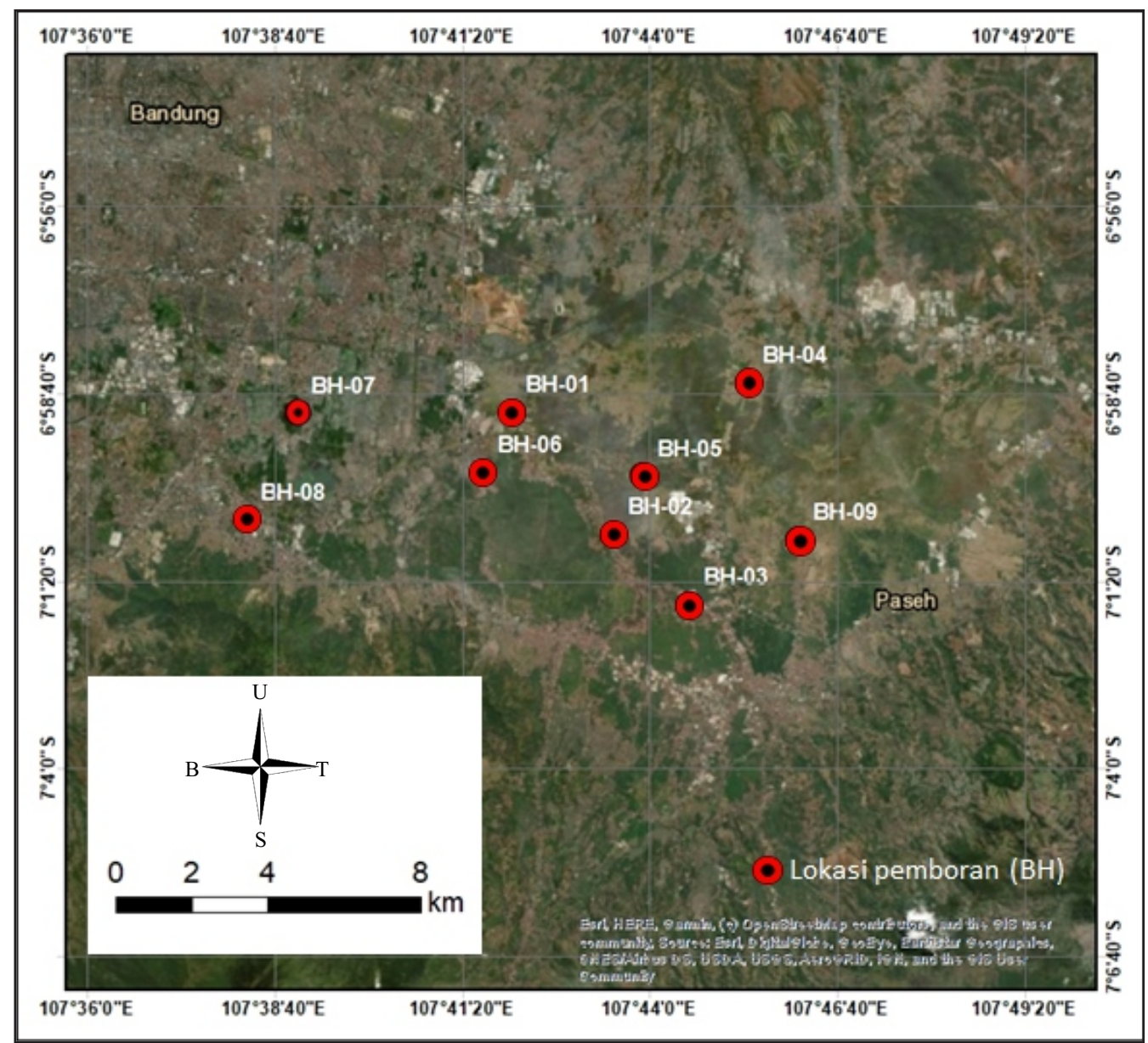

Gambar 1. Peta area penelitian pemodelan banjir bandang Sambelia (kotak merah).

(ukuran partikel $<0,075 \mathrm{~mm}$ ) dengan menggunakan uji saringan menurut ASTM D-422.

Nilai percepatan tanah puncak (PGA) yang dihasilkan oleh gempa bumi yang bersumber dari zona sesar ditentukan dengan menggunakan fungsi atenuasi Boore drr. (1997) sebagai berikut: $\log Y=b_{1}+b_{2}(M-6)+b_{3}(M-6)^{2}+b_{4} r+b_{s} \log r+b_{v}\left(\log V_{s 30}-\log V_{A}\right)$

Dengan keterangan $Y$ adalah percepatan tanah horizontal $(\mathrm{g}), M$ adalah magnitudo gempa bumi, $V_{\mathrm{s} 30}=180 \mathrm{~m} /$ detik, $r-\sqrt{d^{2}+h^{2}}$, dengan $d$ adalah jarak episenter, $b_{1}=-0,105, b_{2}=0,229$, $b_{3}=0, b_{4}=0, b_{5}=-0,778, b_{v}=-0,371, h=5,57$, dan $V_{A}=1400$. 
Sedangkan nilai PGA untuk gempa bumi yang bersumber dari zona subduksi diperoleh berdasarkan fungsi atenuasi Zhao drr. (2006) di bawah ini:

$\operatorname{In} Y=a M_{w}+b x-\operatorname{In}(r)+e\left(h-h_{c}\right) \delta_{h}+S_{R}+S_{1}+S_{S}+S_{S L} \operatorname{In}(x)+C_{k}$

Dengan keterangan $Y$ adalah percepatan tanah puncak $\left(\mathrm{cm} / \mathrm{s}^{2}\right), \mathrm{M}_{\mathrm{w}}$ adalah magnitudo momen, $x$ adalah jarak episenter $(\mathrm{km}), h$ adalah kedalaman hiposenter $(\mathrm{km}), h_{c}$ adalah kedalaman konstan sebesar $15 \mathrm{~km}, \delta_{h}$ adalah variabel dummy sebesar 1 untuk $\mathrm{h}>h_{c}, S_{R}=0, S_{I}=0$, $S_{S}=0, S_{S L}=0$, dan $C_{k}=4$ untuk tanah lunak, dan $a=1,101, b=-0.00564, c=0,0055, d=$ $1,080, e=0,01412, S_{R}=0,251, S_{I}=0, S_{S}=2,607$, $S_{S L}=-0,528$.

Evaluasi potensi likuefaksi dilakukan dengan menentukan faktor keamanan (FK) terhadap likuefaksi yang merupakan perbandingan rasio tegangan siklik atau Cyclic Stress Ratio (CSR) dengan rasio hambatan siklik atau Cyclic Resistance Ratio (CRR). Perhitungan CSR dilakukan berdasarkan persamaan Seed \& Idriss (1971) sebagai berikut:

$$
C S R_{M, \sigma_{v}^{1}}=0,65 \frac{a_{\max }}{g} \frac{\sigma_{v}}{\sigma_{v}^{1}} r_{d}
$$

Dengan keterangan $\sigma_{v}$ adalah tegangan vertikal total pada kedalaman $\mathrm{z}, \sigma^{1}{ }_{v}$ adalah tegangan vertikal efektif pada kedalaman $z, \mathrm{a}_{\max }$ adalah percepatan horizontal maksimum tanah, $g$ adalah percepatan gravitasi, dan $r_{d}$ adalah faktor reduksi tegangan geser yang menyumbang respon dinamis dari profil tanah.

Sementara itu, perhitungan nilai $C R R$ berdasarkan data $S P T$ dilakukan dengan metode Boulanger \& Idriss (2014) sebagai berikut:

$$
C R R_{7,5}=\exp \frac{\left(N_{1}\right)_{60 c s}}{14,1}+\left(\frac{\left(N_{1}\right)_{60 c s}}{126}\right)^{2}-\left(\frac{\left(N_{1}\right)_{60 c s}}{23,6}\right)^{3}+\left(\frac{\left(N_{1}\right)_{60 c s}}{25,4}\right)^{4}-2,8
$$

Dengan keterangan $C R R_{7,5}$ adalah nilai rasio hambatan siklik untuk magnitudo gempa bumi
$M_{w}=7,5$ dan $\left(N_{p}\right)_{60 c s}$ adalah nilai ekuivalen pasir bersih untuk hambatan penetrasi standar ternormalisasi.

Hasil perhitungan $C S R$ dan $C R R_{7,5}$ digunakan untuk mengetahui faktor keamanan $(F K)$ terhadap likuefaksi dengan menggunakan persamaan berikut (Boulanger dan Idriss, 2014):

$F K=\frac{C R R_{7,5}}{C S R} \cdot M S F \cdot K \sigma$

Dengan keterangan MSF (Magnitude Scaling Factor) adalah faktor kelipatan besaran gempa bumi dan $\mathrm{K}_{\sigma}$ adalah faktor koreksi beban lapisan tanah berdasarkan persamaan Boulanger \& Idriss (2014). Batasan nilai $F K$ yang digunakan adalah $F K<1$ untuk lapisan pasir rentan terhadap likuefaksi dan $F K>1$ untuk lapisan pasir tidak rentan terhadap likuefaksi (Tohari drr., 2015).

Penurunan tanah akibat likuefaksi dihitung dengan persamaan Ishihara dan Yoshimine (1992) sebagai berikut:

$S=\sum_{i=1}^{N} \varepsilon_{v} \Delta z i$

Dengan keterangan $S$ merupakan penurunan tanah total, $\varepsilon_{v}$ adalah regangan volumetrik pada setiap ketebalan lapisan tanah ke-i $(\Delta z i)$.

\section{HASIL DAN PEMBAHASAN}

Gambar 2 hingga Gambar 4 menyajikan grafik SPT dan persentase kandungan partikel halus serta jenis lapisan tanah di semua lokasi pemboran. Pada umumnya, lapisan tanah didominasi oleh lempung lunak hingga sangat kaku dengan sisipan lapisan pasir lepas hingga sangat padat. Pada lokasi BH-01 (Gambar 2(a), lapisan pasir lepas hingga sangat padat dijumpai pada kedalaman 9 - 12 m, 17 - 18, 22 - 24 m, dan 28,5 - 30 m. Pada lokasi BH-02, terdapat lapisan pasir lepas pada kedalaman 15 - 16 m, lihat Gambar 2(b). Sementara itu berdasarkan data bor BH-03 pada Gambar 2(c), lapisan pasir lepas ditemukan pada kedalaman 4 - 6 m. Dengan demikian, 


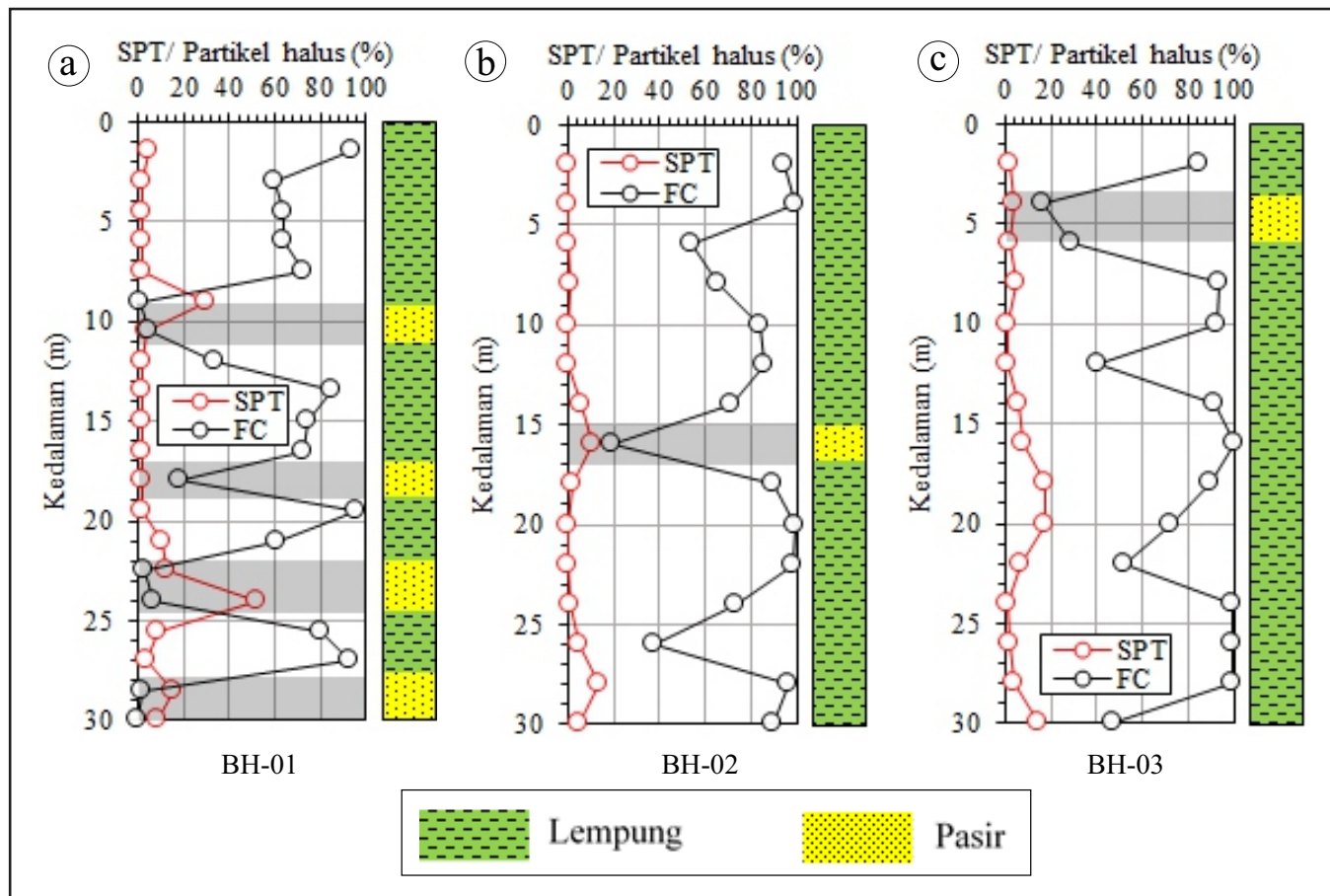

Gambar 2. Plot nilai SPT dan persentase kandungan partikel halus (FC) menurut kedalaman. Lapisan pasir diberi tanda kotak warna abu-abu muda.

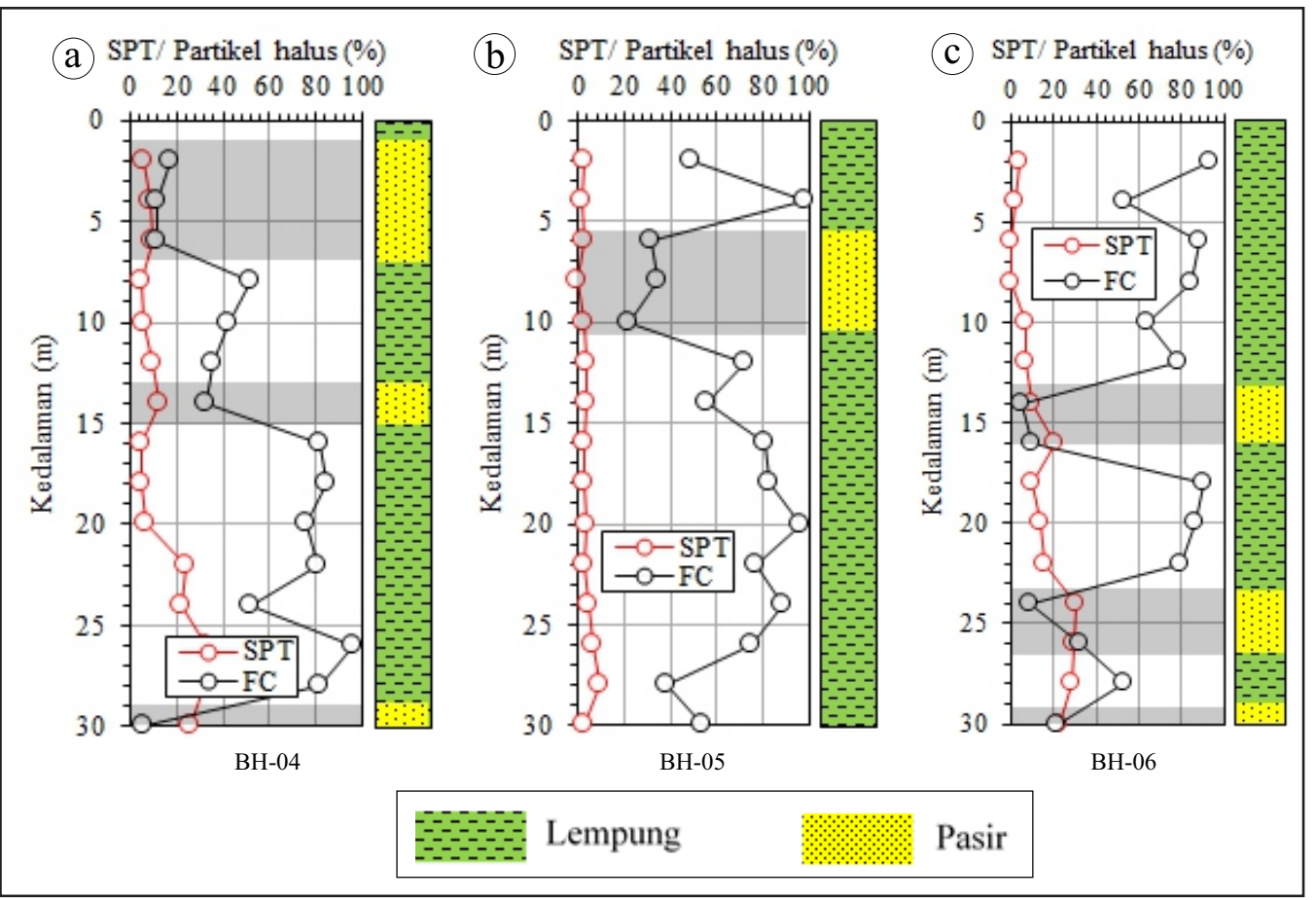

Gambar 3. Plot nilai SPT dan persentase kandungan partikel halus (FC) menurut kedalaman. Lapisan pasir diberi tanda kotak warna abu-abu muda.

terdapat lapisan pasir lepas yang berpotensi likuefaksi pada kedalaman yang bervariasi di ketiga lokasi ini.
Pada lokasi titik bor BH-04 Gambar 3(a), lapisan pasir lepas dijumpai pada kedalaman 2 - $6 \mathrm{~m}$, dan lapisan pasir dengan kepadatan medium 


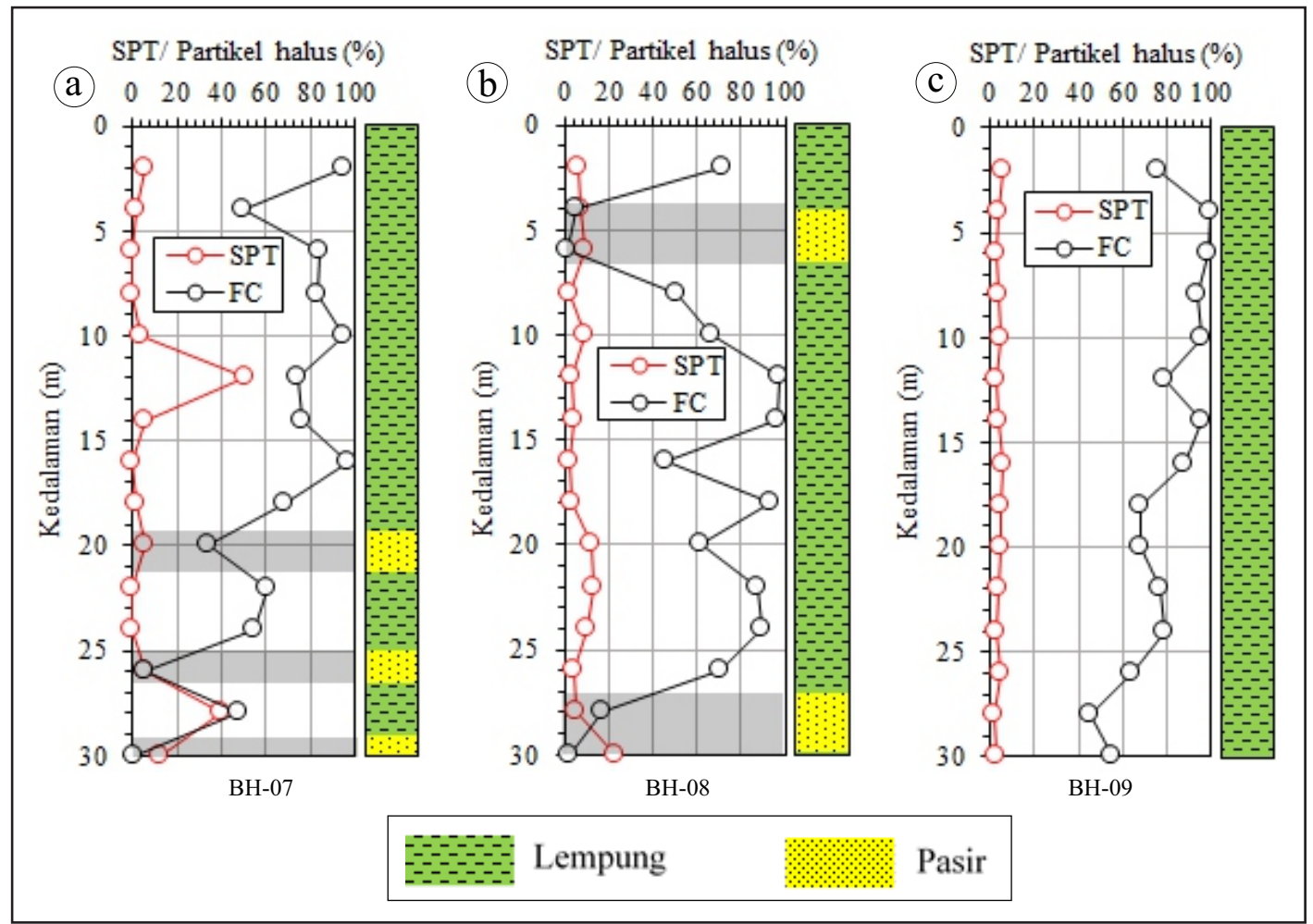

Gambar 4. Plot nilai SPT dan persentase kandungan partikel halus (FC) menurut kedalaman. Lapisan pasir diberi tanda kotak warna abu-abu muda

pada kedalaman $14 \mathrm{~m}$ dan $30 \mathrm{~m}$. Sementara itu berdasarkan data bor BH-05 (Gambar 3(b), pada kedalaman 6 - 10 m dijumpai lapisan pasir sangat lepas. Pada titik bor BH-06 (Gambar 3(c), lapisan pasir dengan kepadatan medium hingga padat dijumpai pada kedalaman 14 - $16 \mathrm{~m}$ serta pada kedalaman 24 - $26 \mathrm{~m}$. Dengan demikian, terdapat lapisan pasir lepas hingga medium yang kemungkinan dapat mengalami likuefaksi di setiap lokasi pemboran ini.

Data bor BH-07 (Gambar 4(a) menunjukkan bahwa sisipan lapisan pasir lepas dijumpai pada kedalaman 20 dan $26 \mathrm{~m}$, dan lapisan pasir dengan kepadatan medium pada kedalaman 29 - 30 $\mathrm{m}$. Lapisan pasir dengan kepadatan lepas juga dijumpai pada kedalaman 4 - $6 \mathrm{~m}$ dan lapisan pasir dengan kepadatan medium pada kedalaman 28 - 30 m di lokasi titik bor BH-08 Gambar 4(b). Sementara itu berdasarkan data bor BH-09 Gambar 4(c), tidak dijumpai adanya lapisan pasir di lokasi titik bor tersebut. Berdasarkan data pemboran di tiga lokasi ini, fenomena likuefaksi hanya dapat terjadi di lokasi BH-07 dan BH-08.
Gambar 5 menyajikan plot kurva gradasi ukuran butiran sampel pasir dari lokasi pemboran pada kurva zona likuefaksi (menurut Tsuchida, 1970). Kurva ukuran butiran mengindikasikan bahwa lapisan pasir di semua lokasi berada pada zona kemungkinan likuefaksi tinggi. Dengan demikian, lapisan pasir di daerah Cekungan Bandung mempunyai potensi untuk mengalami likuefaksi pada kedalaman yang bervariasi.

Berdasarkan Youd drr. (1979), hubungan kedalaman muka airtanah dengan kerentanan likuefaksi di setiap lokasi pemboran disajikankan pada Tabel 2. Berdasarkan kedalaman muka airtanah, lokasi BH-01, BH-02, BH-05, BH-06 dan BH-08 mempunyai potensi likuefaksi sangat tinggi hingga tinggi. Sementara itu, lokasi BH04 dan BH-07 mempunyai potensi likuefaksi sangat rendah hingga rendah. Sedangkan lokasi BH-09 tidak akan masuk dalam klasifikasi tersebut karena lapisan tanahnya tersusun oleh lapisan lempung. Dengan demikian, potensi likufaksi di daerah Cekungan Bandung sangat bervariasi. Namun, selain kedalaman muka 


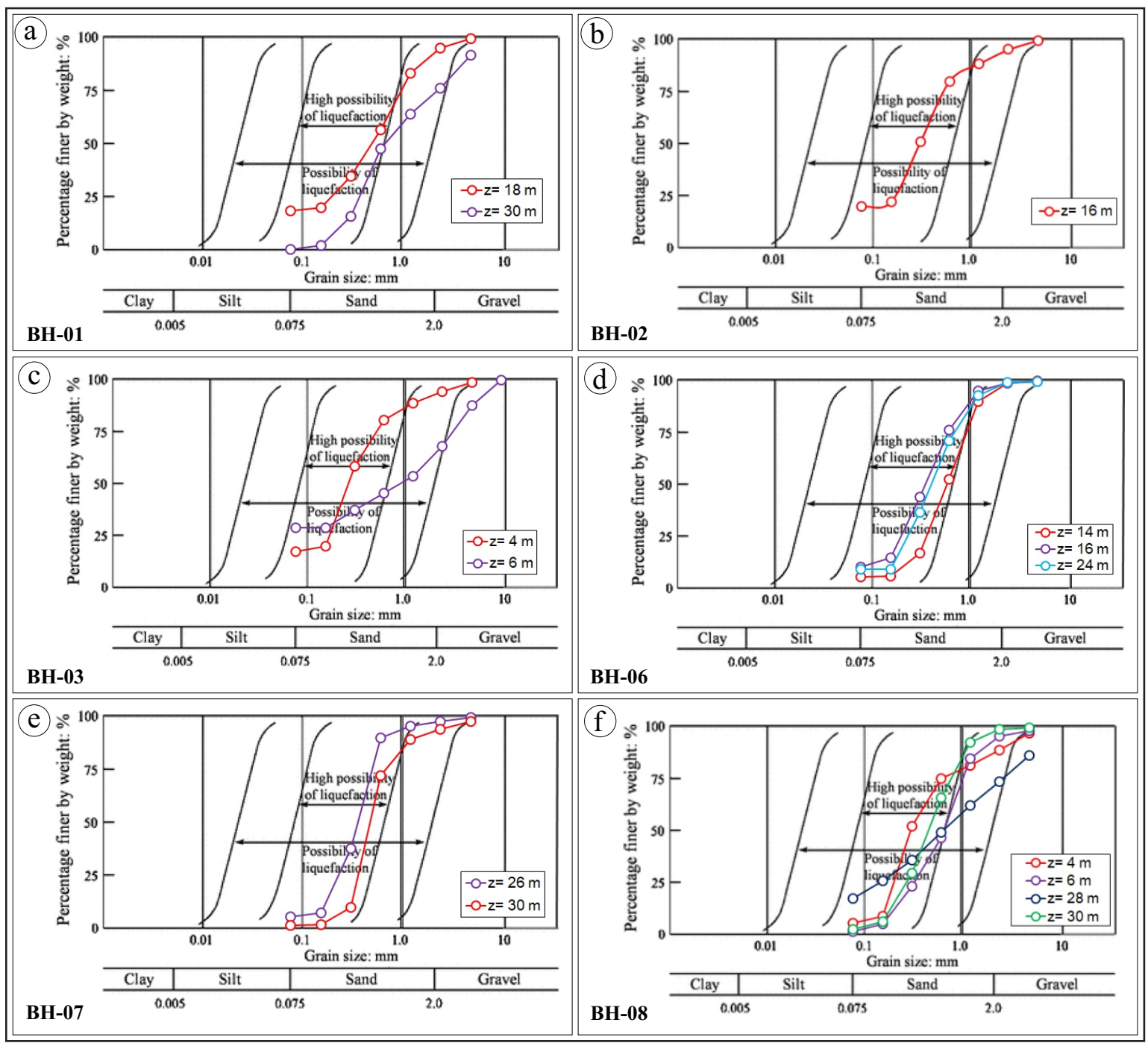

Gambar 5. Kurva gradasi ukuran butiran tanah pada kurva kerentanan likuefaksi (menurut Tsuchida, 1970). Notasi $z$ adalah kedalaman contoh tanah.

Tabel 2. Hubungan kedalaman muka airtanah dan potensi likuefaksi di setiap lokasi pemboran berdasarkan klasifikasi menurut Youd drr. (1979)

\begin{tabular}{|ccc|}
\hline Kode Bor & $\begin{array}{c}\text { Kedalaman muka } \\
\text { airtanah }(\mathbf{m})\end{array}$ & Potensi likuefaksi \\
\hline BH-01 & 1,0 & Sangat tinggi \\
BH-02 & 3,0 & Sangat tinggi - tinggi \\
BH-03 & 3,5 & Tinggi \\
BH-04 & 15,0 & Rendah \\
BH-05 & 7,0 & Tinggi \\
BH-06 & 3,0 & Sangat tinggi-tinggi \\
BH-07 & 15,5 & Sangat rendah \\
BH-08 & 1,5 & Sangat tinggi \\
BH-09 & 10,2 & Tidak likuefaksi \\
\hline
\end{tabular}

airtanah, potensi likuefaksi ini juga dipengaruhi oleh jenis dan kepadatan lapisan tanah. Tingkat potensi likuefaksi akan berkurang pada lapisan yang didominasi oleh lempung. Oleh karena itu, perlu dilakukan analisis potensi likuefaksi dengan memperhitungkan jenis dan kepadatan lapisan tanah serta percepatan tanah puncak di setiap lokasi penelitian.

Tabel 3 menyajikan hasil perhitungan PGA di lokasi penelitian untuk setiap jenis sumber gempa bumi. Nilai PGA akibat gempa bumi Sesar Lembang mempunyai rentang antara $0,19 \mathrm{~g}$ hingga $0,24 \mathrm{~g}$. Sementara itu, nilai PGA akibat sumber gempa bumi di zona subduksi selatan Jawa berkisar antara $0,07 \mathrm{~g}$ hingga 0,08 g. Dengan demikian, gempa bumi akibat Sesar Lembang akan memberikan pengaruh yang lebih besar pada potensi likuefaksi dibandingkan 
Tabel 3. Nilai PGA akibat gempa bumi Sesar Lembang dan zona subduksi

\begin{tabular}{|clcc|}
\hline \multirow{2}{*}{ Kode Bor } & \multicolumn{1}{c|}{ Lokasi } & PGA Sesar Lembang (g) & PGA subduksi Selatan Jawa (g) \\
\hline BH-01 & Desa Tegalluar, Bojongsoang & 0,238 & 0,075 \\
BH-02 & Desa Rancakesumba, Solokan Jeruk & 0,207 & 0,077 \\
BH-03 & Desa Rancakesumba, Solokan Jeruk & 0,191 & 0,078 \\
BH-04 & Kelurahan Rancaekek Kesumba, Rancaekek & 0,229 & 0,072 \\
BH-05 & Desa Bojongemas, Solokan Jeruk & 0,217 & 0,075 \\
BH-06 & Desa Sumbersari, Ciparay & 0,223 & 0,077 \\
BH-07 & GBA, Desa Cipalago, Bojongsoang & 0,233 & 0,078 \\
BH-08 & Baleendah Permai, Desa Baleendah & 0,207 & 0,082 \\
BH-09 & Desa Padamukti, Solokan Jeruk & 0,196 & 0.078 \\
\hline
\end{tabular}

dengan sumber gempa bumi di zona subduksi pada daerah Cekungan Bandung.

Hubungan antara PGA akibat gempa bumi dengan jarak daerah penelitian dapat dilihat pada Gambar 6. Berdasarkan gambar tersebut, nilai PGA terbalik dengan jarak sumber gempa bumi. Semakin besar jarak sumber gempa bumi maka semakin kecil nilai PGA.

Gambar 7 hingga Gambar 9 menunjukkan hasil analisis potensi likuefaksi berdasarkan data $N-S P T$ di beberapa titik bor. Hasil analisis menunjukkan gempa bumi akibat Sesar Lembang dapat menyebabkan likuefaksi di seluruh lokasi penelitian kecuali lokasi BH09, sedangkan gempa bumi di zona subduksi hanya akan menyebabkan likuefaksi di lokasi BH-01. Berdasarkan gambar tersebut dapat dilihat bahwa potensi likuefaksi di setiap lokasi bervariasi, karena dipengaruhi oleh perbedaan percepatan tanah puncak, kedala- man muka airtanah dan ketebalan lapisan pasir lepas hingga medium.

Pada titik bor BH-01 potensi likuefaksi terjadi pada lapiran pasir pada kedalaman 10,5 - 12 $\mathrm{m}, 18 \mathrm{~m}, 22,5 \mathrm{~m}$ dan 28,5 - $30 \mathrm{~m}$ akibat gempa bumi Sesar Lembang. Pada titik bor BH-02, lihat Gambar 7(b), potensi likuefaksi hanya terjadi pada sisipan lapisan pasir di kedalaman $16 \mathrm{~m}$, sedangkan sisipan lapisan pasir pada kedalaman 4 - $6 \mathrm{~m}$ berpotensi likuefaksi pada titik bor BH03 Gambar 7(c). Sementara itu, lapisan pasir lepas di lokasi BH-01 pada kedalaman 10,5-12 $\mathrm{m}$ dapat mengalami likuefaksi akibat gempa bumi dari zona subduksi.

Akibat gempa bumi Sesar Lembang, likuefaksi hanya akan terjadi pada lapisan pasir lepas pada kedalaman 0 - 6 m Pada titik bor BH-04 Gambar 8(a). Pada titik bor BH-05 Gambar 8(b), lapisan pasir pada kedalaman 6 - $10 \mathrm{~m}$ berpotensi likuefaksi. Sementara itu, potensi

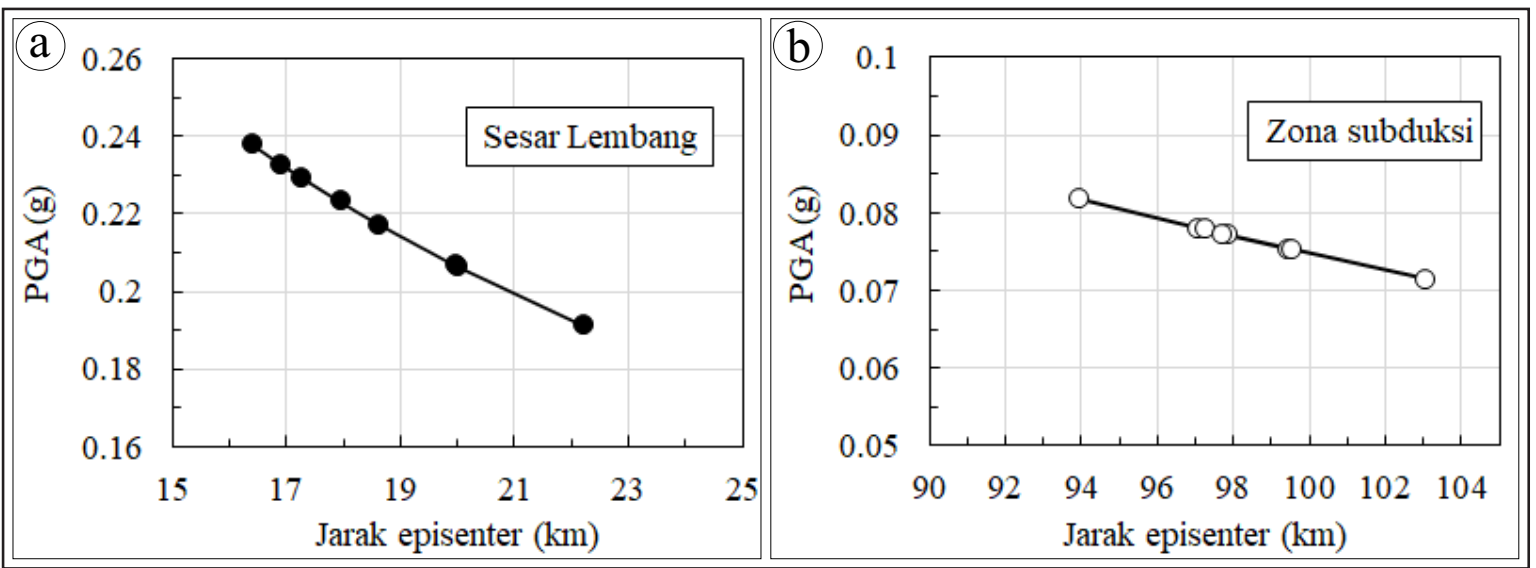

Gambar 6. Grafik hubungan antara jarak episenter dari daerah penelitian dan percepatan tanah puncak (PGA) akibat gempa bumi Sesar Lembang dan gempa bumi zona subduksi selatan Jawa. 


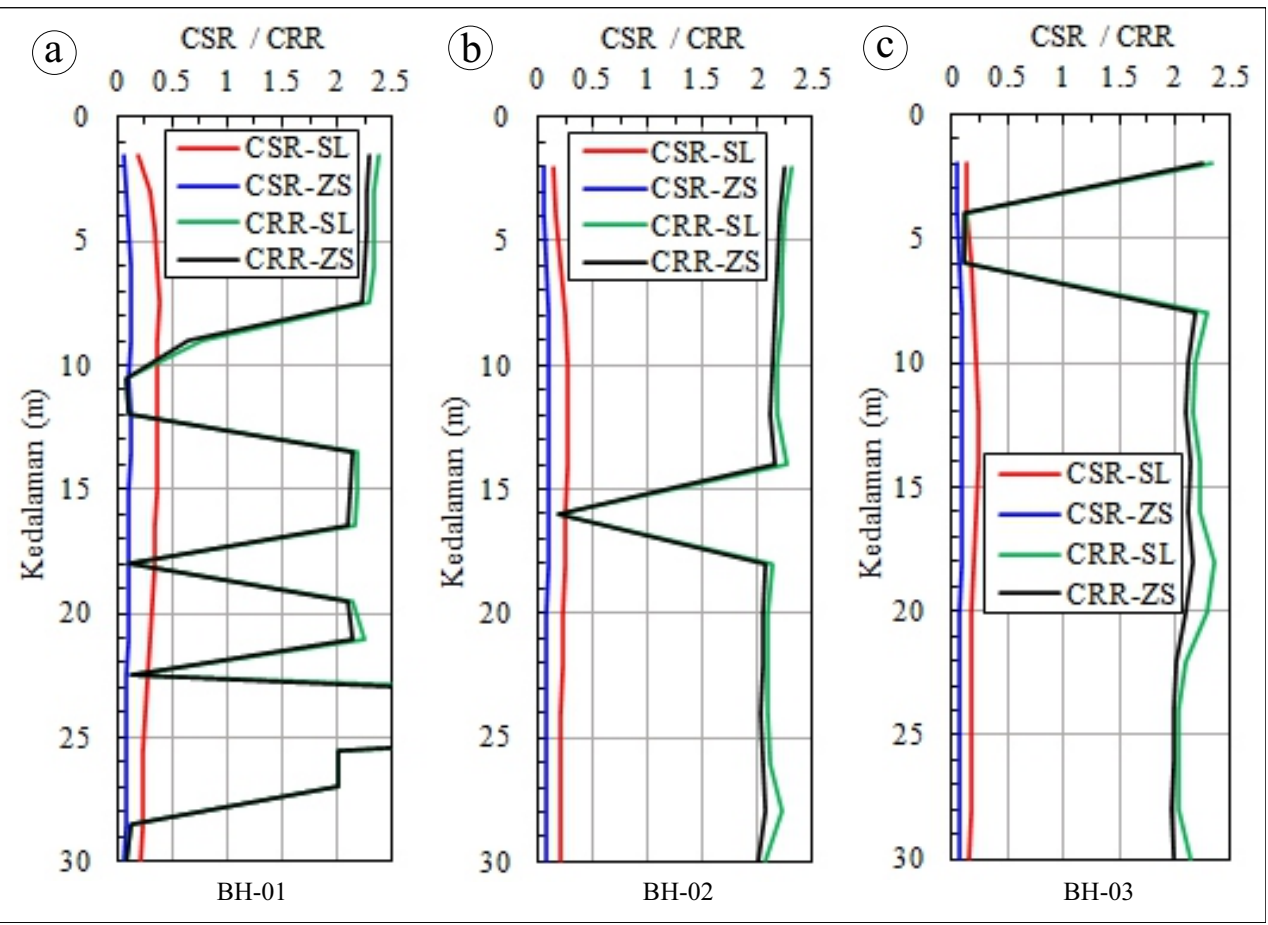

Gambar 7. Grafik CSR dan CRR terhadap kedalaman $(\mathrm{SL}=$ Sesar Lembang dan ZS = zona subduksi).

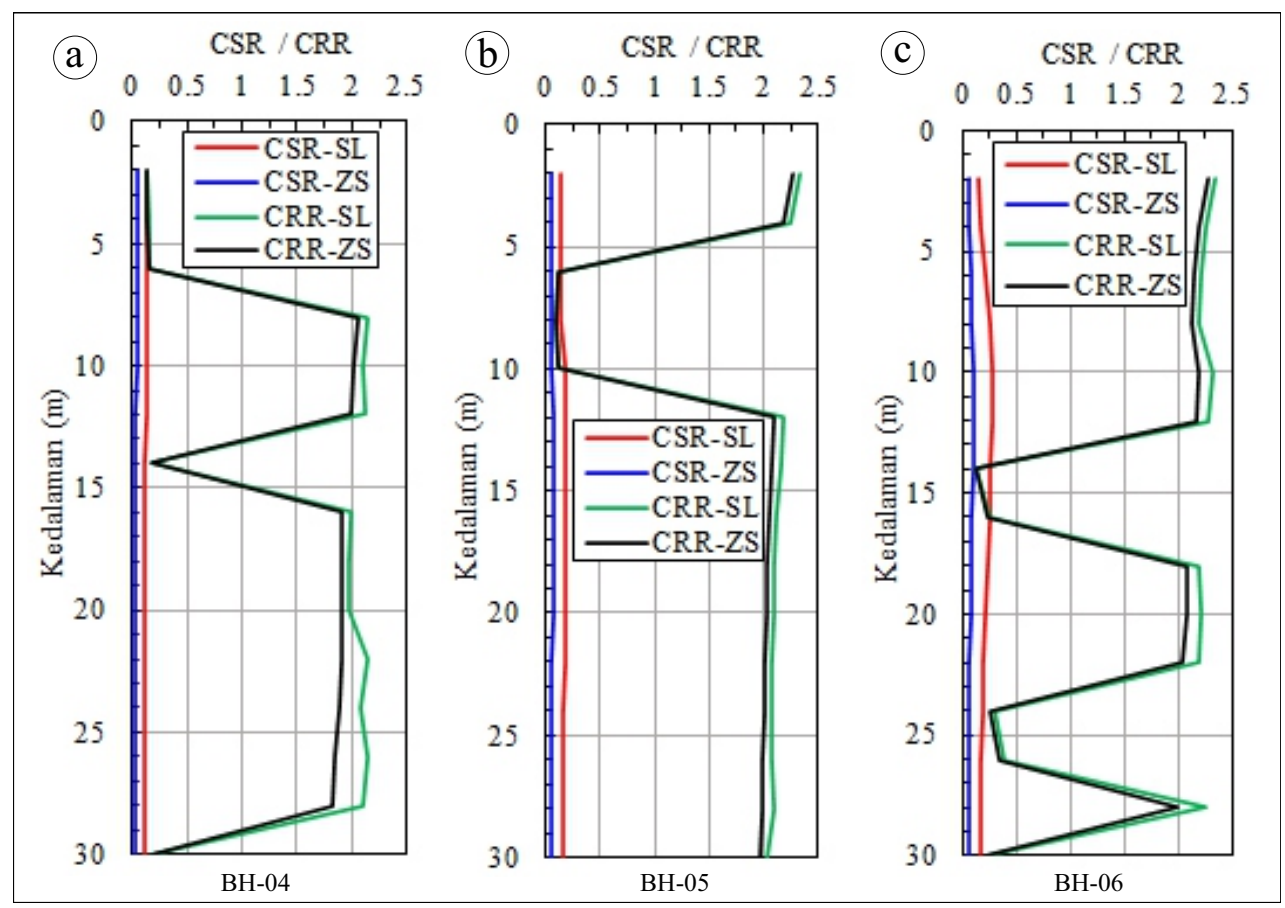

Gambar 8. Grafik CSR dan CRR terhadap kedalaman ( $\mathrm{SL}=$ Sesar Lembang dan ZS = zona subduksi).

likuefaksi akan terjadi pada lapisan pasir lepas mulai dari kedalaman 14 - 16 m pada titik bor BH-06 Gambar 8(c).

Pada titik bor BH-07 Gambar 9(a), gempa bumi Sesar Lembang akan menyebabkan potensi likuefaksi pada kedalaman 20 m, 26 m, dan 30 . Pada titik bor BH-08 Gambar 9(b), likuefaksi akan terjadi pada kedalaman 4 hingga $6 \mathrm{~m}$ dan 28 hingga $30 \mathrm{~m}$ akibat adanya gempa bumi Sesar Lembang. Sedangkan lapisan tanah pada 


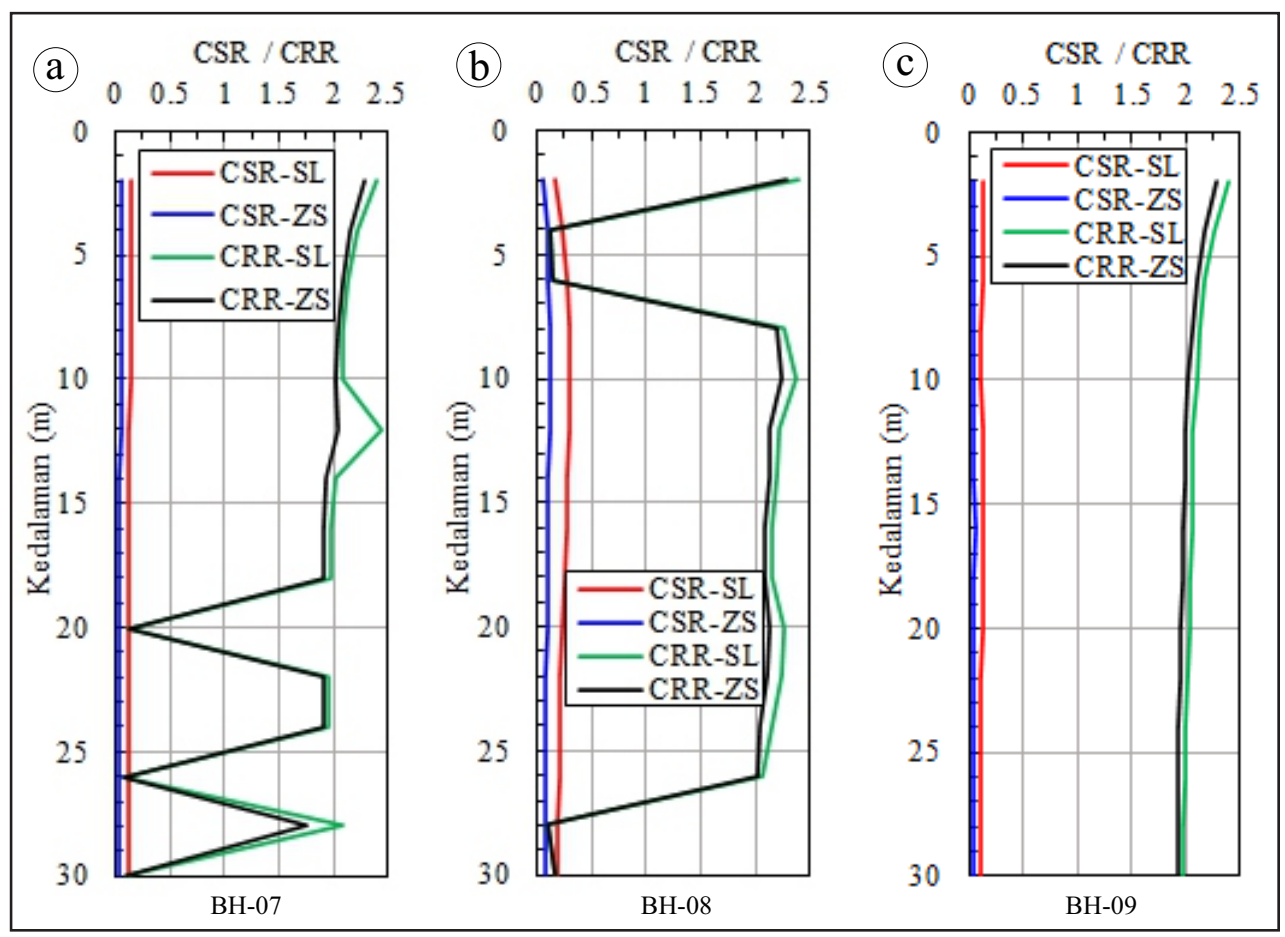

Gambar 9. Grafik CSR dan CRR terhadap kedalaman (SL = Sesar Lembang dan ZS = zona subduksi).

titik bor BH-09 Gambar 9(c) tidak berpotensi, karena keberadaan lapisan lempung lunak dari permukaan tanah.

Berdasarkan hasil analisis potensi likuefaksi pada setiap lokasi titik bor, likuefaksi dapat terjadi pada lapisan pasir lepas hingga medium pada kedalaman lebih dari $5 \mathrm{~m}$. Hasil analisis ini menunjukkan bahwa kedalaman maksimum di mana likuefaksi dapat terjadi itu ditentukan oleh keberadaan lapisan pasir dengan densitas rendah, kedalaman muka airtanah, dan nilai percepatan tanah puncak di setiap lokasi.

Gambar 10 hingga Gambar 12 menyajikan grafik penurunan tanah akibat likuefaksi di setiap lubang bor. Besarnya penurunan tanah total akibat likuefaksi di setiap lokasi bervariasi karena adanya perbedaan ketebalan lapisan yang mengalami likuefaksi. Penurunan tanah total yang diakibatkan oleh gempa bumi Sesar Lembang hampir terjadi di seluruh lokasi titik bor, kecuali titik bor BH-09, dengan besar penurunan tanah total hingga 40,75 cm pada titik BH-01. Penurunan tanah akibat likuefaksi oleh gempa bumi zona subduksi selatan Jawa hanya terjadi pada titik bor BH-01 dengan besar penurunan tanah total $22,04 \mathrm{~cm}$.
Gambar 13 menyajikan peta zonasi penuruan tanah berdasarkan hasil perhitungan penurunan tanah akibat likuefaksi dengan mempertimbangkan nilai PGA Sesar Lembang $\left(\mathrm{M}_{\mathrm{w}} 6,5\right) \mathrm{di}$ setiap lokasi pemboran teknik. Secara umum, lapisan endapan danau di daerah Cekungan Bandung dapat mengalami penurunan tanah berkisar antara $0 \mathrm{~cm}$ dan $45 \mathrm{~cm}$. Lapisan tanah di daerah Cekungan Bandung bagian timur, termasuk Kecamatan Solokan Jeruk dan Ciparay, akan mengalami penurunan tanah antara 0 $-20 \mathrm{~cm}$, sedangkan wilayah bagian barat akan mengalami penurunan tanah antara $20-40 \mathrm{~cm}$. Hal ini terasosiasikan dengan lapisan tanah pasir lepas dan jenuh air di wilayah bagian barat yang lebih tebal dibandingkan dengan lapisan tanah pasir di wilayah bagian timur sebagaimana dapat dilihat pada Gambar 2 hingga Gambar 4. Dengan demikian, wilayah bagian barat akan mempunyai potensi risiko likuefaksi yang lebih tinggi dibandingkan dengan wilayah bagian timur.

Gambar 13 juga mengindikasikan bahwa daerah Cekungan Bandung bagian utara mempunyai potensi risiko penurunan tanah yang lebih tinggi 


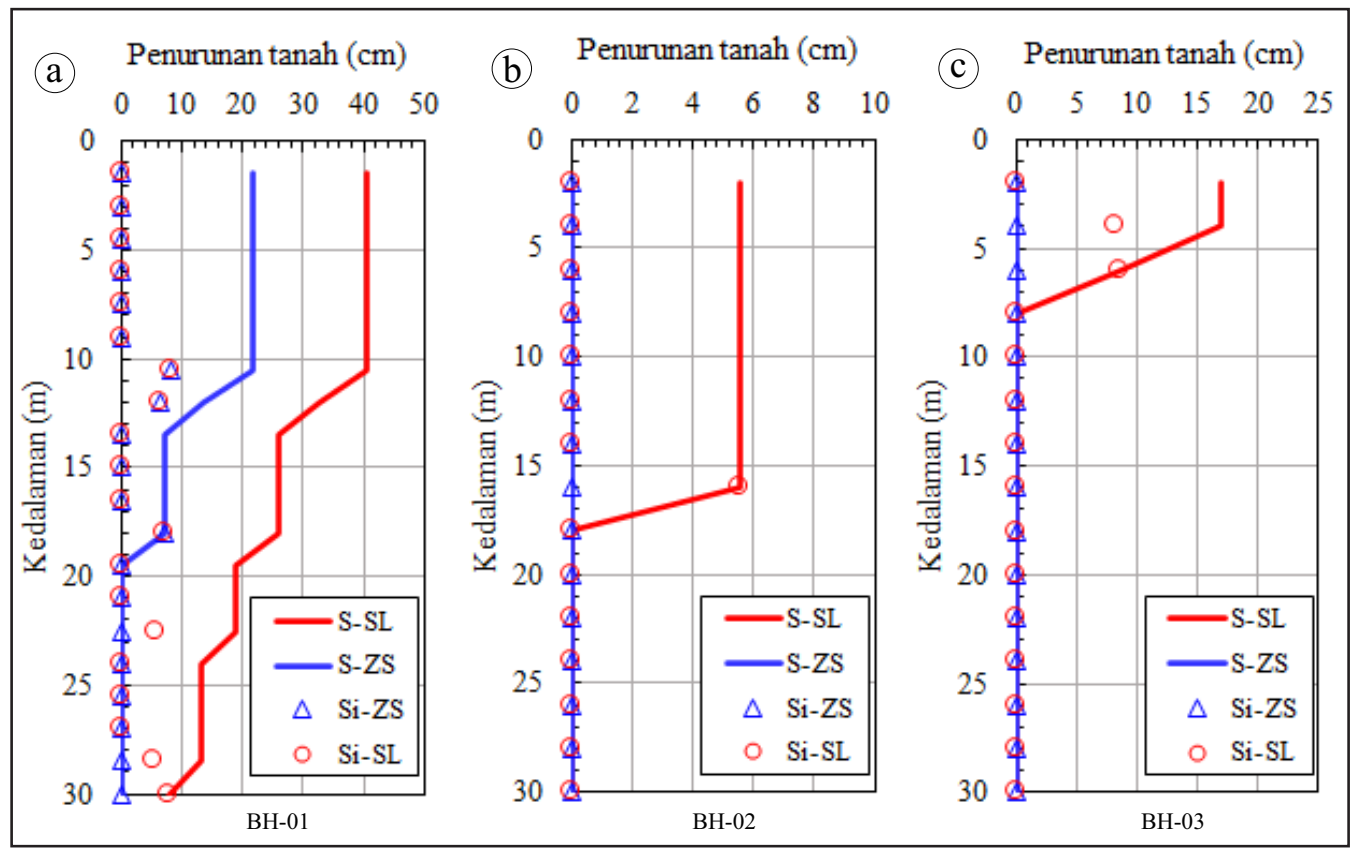

Gambar 10. Grafik penurunan tanah total $(S)$ dan nilai penurunan pada setiap lapisan tanah $(S i)$ akibat likuefaksi yang dipicu oleh gempa bumi Sesar Lembang (SL) dan zona subduksi (ZS).

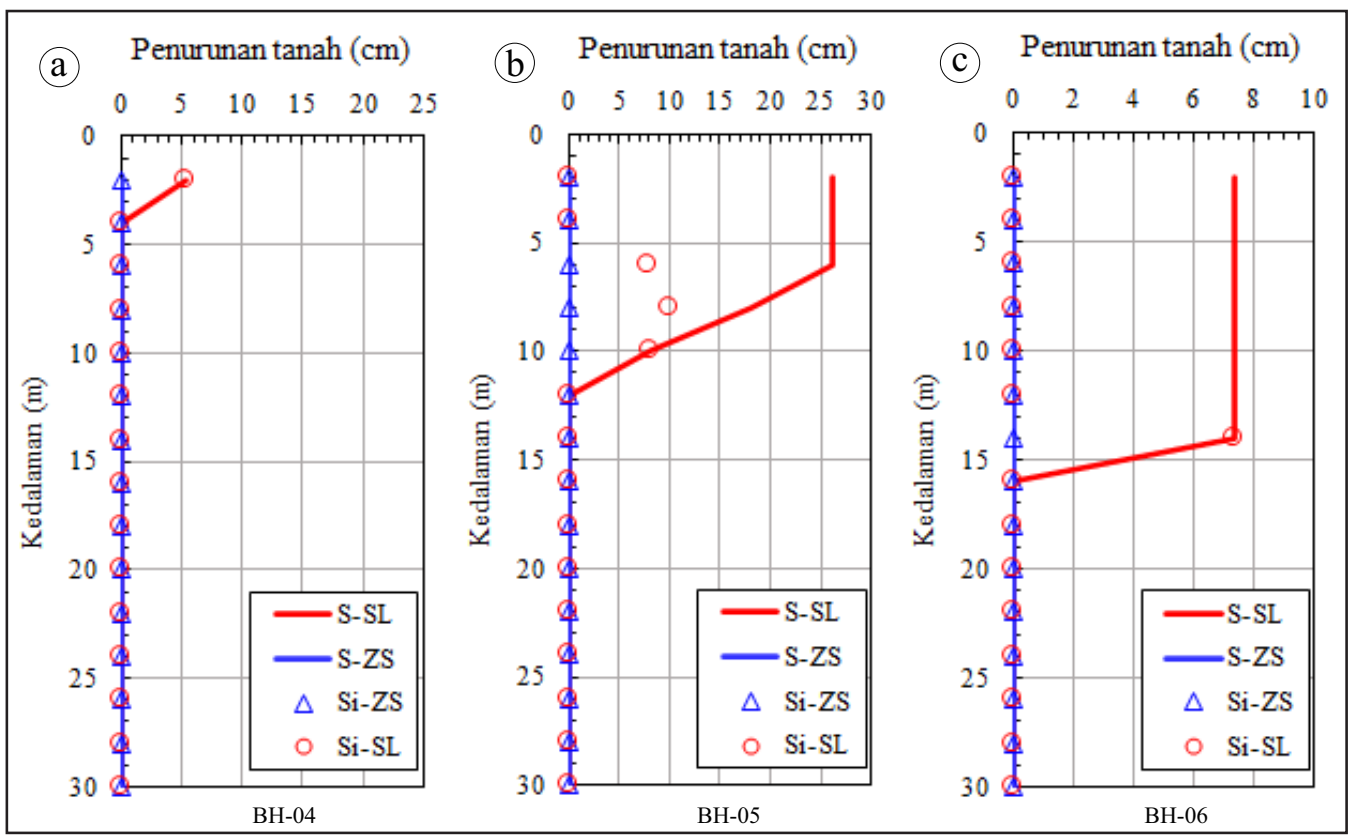

Gambar 11. Grafik penurunan tanah total $(S)$ dan nilai penurunan pada setiap lapisan tanah $(S i)$ akibat likuefaksi yang dipicu oleh gempa bumi Sesar Lembang (SL) dan zona subduksi (ZS).

dibandingkan wilayah bagian Selatan. Lapisan tanah di wilayah Desa Tegalluar, Kecamatan Bojongsoang, memiliki nilai penurunan tanah terbesar karena terdapat lapisan pasir lepas yang tebal dan jenuh air di beberapa kedalaman di bawah permukaan tanah. Selain itu, lapisan tanah di wilayah ini memiliki nilai PGA yang tertinggi karena berada pada jarak terdekat dari sumber gempa bumi Sesar Lembang.

Daerah dataran Cekungan Bandung tersusun endapan danau purba yang terdiri atas bahan lepas berukuran lempung, lanau, pasir, dan 


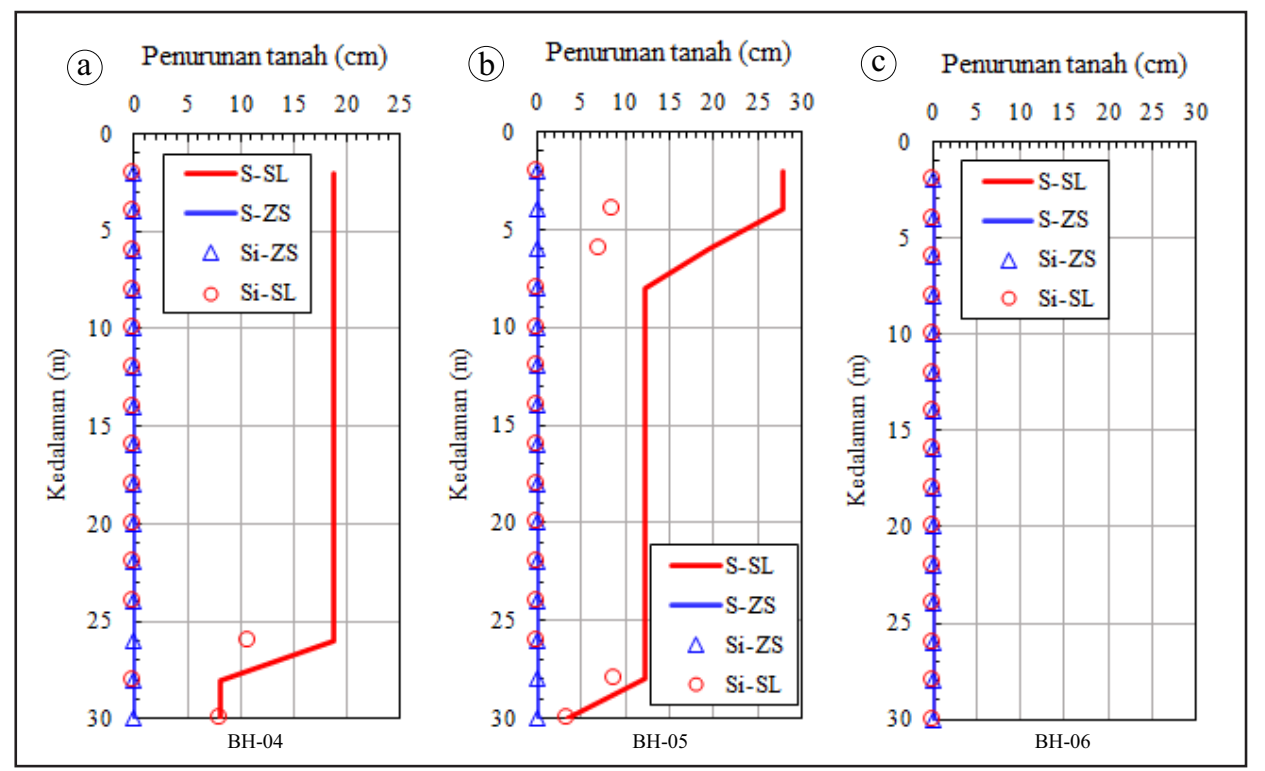

Gambar 12. Grafik penurunan tanah total $(S)$ dan nilai penurunan pada setiap lapisan tanah $(S i)$ akibat likuefaksi yang dipicu oleh gempa bumi Sesar Lembang (SL) dan zona subduksi (ZS).

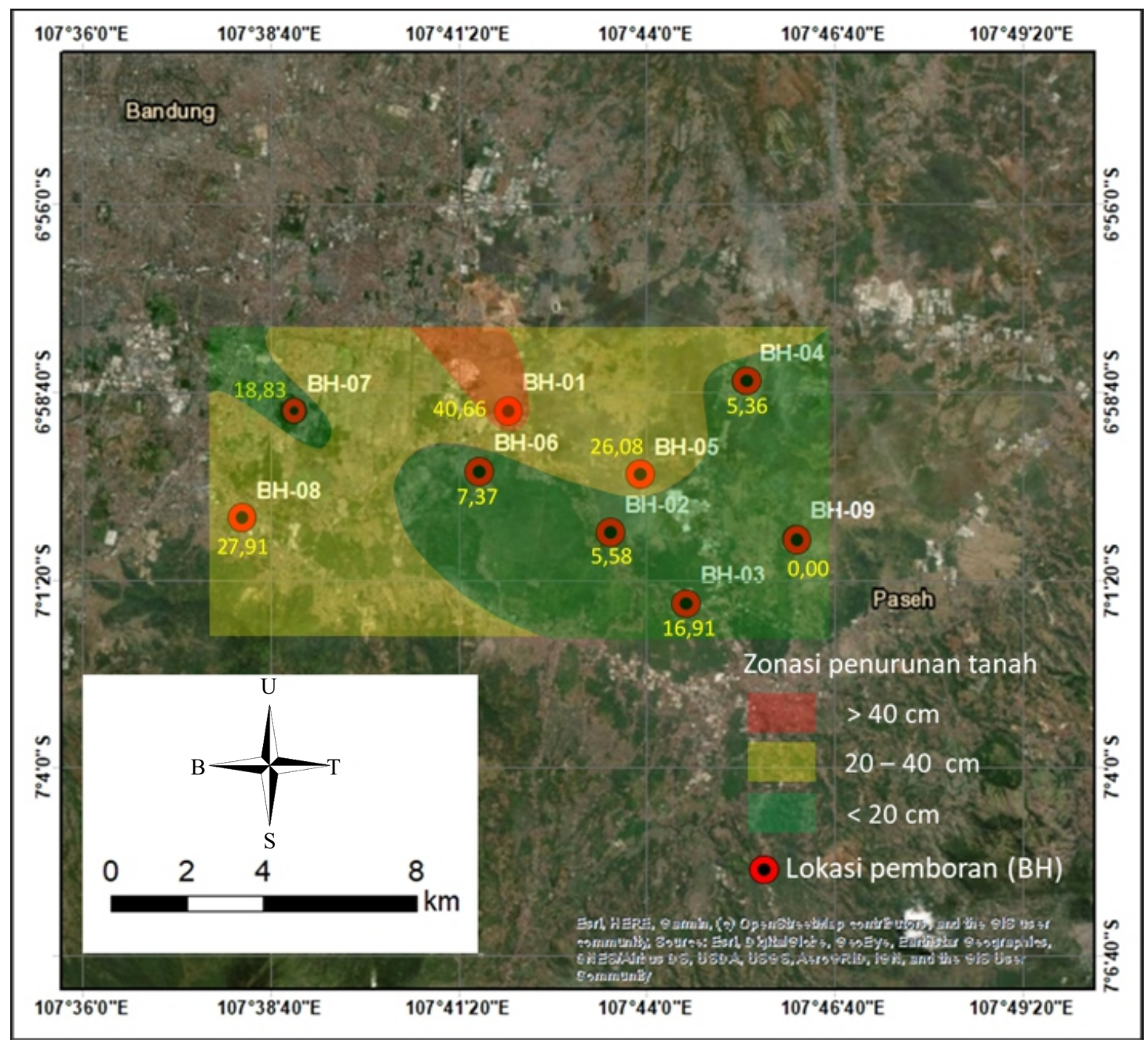

Gambar 13. Zonasi penurunan tanah akibat likuefaksi untuk daerah Cekungan Bandung berdasarkan data SPT. 
Analisis Potensi Likuefaksi di Daerah Cekungan Bandung Berdasarkan Data Standard Penetration Test (SPT)

kerikil yang bersifat tufan yang sangat rentan terhadap guncangan seismik (Handayani drr., 2009). Sementara daerah pegunungan yang mengitari Cekungan Bandung umumnya terbentuk oleh batuan gunung api yang lebih kuat menahan guncangan. Hasil analisis potensi likuefaksi memperlihatkan bahwa potensi likuefaksi di daerah Cekungan Bandung sangat bervariasi sehingga dampak penurunan tanah akibat likuefaksi juga bervariasi dari satu lokasi ke lokasi lainnya. Selain jenis lapisan tanah, ketebalan lapisan pasir juga menjadi faktor-faktor yang mengontrol besaran penurunan tanah. Pada daerah yang tersusun oleh lapisan lempung dengan sisipan-sisipan pasir lepas hingga medium, penurunan tanah akibat likuefaksi akan semakin besar. Selain itu, semakin dalam muka airtanah, potensi penurunan tanah akibat likuefaksi juga semakin rendah meskipun lapisan pasir lepas hingga medium cukup tebal.

Likuefaksi aliran (flow liquefaction) merupakan salah satu tipe likuefaksi yang menimbulkan kerusakan dan korban jiwa yang sangat besar seperti yang terjadi di Kota Palu dan Kabupaten Sigi akibat gempabumi $\mathrm{M}_{\mathrm{w}}$ 7,4 pada September tahun 2018. Likuefaksi aliran terjadi pada lapisan pasir atau lanau jenuh pada suatu lereng dengan kemiringan lebih dari $3^{\circ}$ (National Research Council, 1985). Mempertimbangkan kondisi geomorfologi bagian tengah dari daerah Cekungan Bandung, likuefaksi aliran tidak akan terjadi karena morfologi daerah tersebut termasuk kategori dataran. Berdasarkan hasil analisis potensi likuefaksi, daerah pedataran di daerah Cekungan Bandung berpotensi untuk mengalami penurunan tanah sehingga bangunan yang tidak mempunyai pondasi yang kuat dapat mengalami amblesan. Flow liquefaction juga tidak akan terjadi di daerah pegunungan yang mengitari Cekungan Bandung dan berada di sekitar zona Sesar Lembang karena daerah tersebut umumnya terbentuk oleh lapisan batuan gunung api yang lebih kuat menahan guncangan akibat gempa bumi, meskipun kemiringan daerah tersebut lebih dari $3^{\circ}$.

\section{KESIMPULAN}

Berdasarkan hasil penelitian potensi likuefaksi pada titik bor yang tersebar di beberapa lokasi di Daerah Cekungan Bandung, lapisan tanah didominasi oleh lapisan lempung lunak dengan sisipan pasir sangat lepas hingga padat pada beberapa kedalaman. Pengaruh percepatan tanah puncak terhadap potensi likuefaksi akibat gempa bumi Sesar Lembang $\left(M_{w} 6,5\right)$ lebih besar daripada gempa bumi di zona subduksi $\left(\mathrm{M}_{\mathrm{w}}\right.$ $7,0)$. Berdasarkan kondisi geologi, hidrologi dan kegempaan, likuefaksi dapat terjadi hingga kedalaman $30 \mathrm{~m}$. Akibat perbedaan kondisi lapisan tanah dan kedalaman muka airtanah, likuefaksi menyebabkan penurunan tanah yang berbeda-beda di setiap lokasi dengan penurunan tanah total maksimum terjadi di Desa Tegalluar, Kecamatan Bojongsoang. Hasil analisis ini memperlihatkan pentingnya penyusunan peta mikrozonasi kerentanan penurunan tanah akibat likuefaksi di daerah Cekungan Bandung. Dengan mempertimbangkan kondisi geologi dan kedalaman muka airtanah di daerah Cekungan Bandung, maka penyusunan peta mikrozonasi tersebut memerlukan data pemboran teknik yang lebih banyak untuk mewakili variasi jenis, ketebalan dan kepadatan lapisan tanah di wilayah ini.

\section{UCAPAN TERIMAKASIH}

Penulis mengucapkan terima kasih kepada kepala Pusat Penelitian Geoteknologi LIPI yang telah memberikan kesempatan untuk melakukan penelitian ini.

\section{DAFTAR PUSTAKA}

Boore, D. M., Joyner, W. B., dan Fumal, T. E., 1997. Equations for Estimating Horizontal Response Spectra and Peak Acceleration from Western North American Earthquakes: A Summary of recent Work. Seismological Research Letters, Vol. 68 (1), p. 128-153. DOI: 10.1785/ gssrl.68.1.128 
Boulanger, R. and Idriss, I., 2014. CPT dan SPT Based Liquefaction Triggering Procedures. Report No. UCD/CGM.-1/01, Center for Geoech. Modelling, Civil \& Environmental Eng., UC Davis, CA, $134 \mathrm{pp}$.

Hamandi, D., Iskandar, N., dan Salahudin A., 2006. Konservasi Airtanah di Daerah Bandung dan Sekitarnya. Bulletin Geologi Tata Lingkungan, Vol. 16 (2), hal. 41-57.

Daryono, M. R., Natawidjaja, D. H., dan Benjamin Sapiie, P. C., 2019. Earthquake Geology of the Lembang Fault, West Java. Tectonophysics, Vol. 751, hal. 180-191. DOI: $10.1016 /$ j.tecto.2018.12.014

Handayani, L., Mulyadi, D., dan Wardhana, D. D., Nur, W. H. 2009. Percepatan Pergerakan Tanah Maksimum Daerah Cekungan Bandung: Studi Kasus Gempa Sesar Lembang. Jurnal Sumber Daya Geologi, Vol. 19 (5), hal. 333-337.

Hutasoit, L. M., 2009. Kondisi Permukaan Air Tanah dengan dan tanpa Peresapan Buatan di Daerah Bandung: Hasil Simulasi Numerik. Jurnal Geologi Indonesia, Vol. 4 (3), hal. 177-188. DOI: 10.17014/ijog. vol4no3.20093.

Idriss, I. M. dan Boulanger, R., 2008. Soil Liquefaction During Earthquakes. Monograph MNO-12, EERI, Oakland, CA, 261 pp.

Ishihara, K. dan Yoshimine, M., 1992. Evaluation of Settlements in Sand Deposits Following Liquefaction During Earthquakes. Soils and Foundations, 32(1), hal. 173188. DOI: $10.3208 /$ sandf1972.32.173

National Research Council, 1985. Liquefaction of Soils During Earthquakes. Washington, DC: The National Academies Press. DOI: $10.17226 / 19275$.

Mase, L. Z., 2018. Studi Kehandalan Metode Analisis Likuefaksi Menggunakan SPT Akibat Gempa 8,6 Mw, 12 September 2007 di Area Pesisir Kota Bengkulu. Jurnal Teknik Sipil, Vol. 25 (1), hal. 53-60. DOI: $10.5614 \% 2$ Fjts.2018.25.1.7.
Seed, H. B. dan Idriss, I. M., 1971. Simplified Procedure for Evaluation Soil Liquifaction Potential. Journal of soil mechanics and foundation, Division, ASCE, 97(9), hal. 1249-1273.

Stewart, D. dan Knox, R., 1995. What is the Maximum Depth Liquefaction Can Occur? Proceedings of Third International Conference on Recent Advances in Geotechnical Earthquake Engineering and Soil Dynamics, April 2-7, 1995; Volume III, St. Louis, Missouri.

Sulaeman, C. dan Hidayati, S., 2011. Gempa Bumi Bandung 22 Juli 2011. Jurnal Lingkungan dan Bencana Geologi, 2 (3), hal. 185-190. DOI: 10.34126/jlbg.v2i3.30.

Tohari, A., Sugianti, K., Syahbana, A. J., dan Soebowo, E., 2015. Kerentanan Likuefaksi Wilayah Kota Banda Aceh Berdasarkan Metode Uji Penetrasi Konus. Jurnal Riset Geologi dan Pertambangan, 25, hal. 99-110. DOI: 10.14203/risergeo$\operatorname{tam} 2015 . v 25.204$.

Tokimatsu, K. dan Yoshimi, Y., 1983. Empirical Correlation of Soil Liquefaction Based On SPT N-Value And Fines Content. Soils and Foundations, 23(4), hal. 56-74. DOI: 10.3208/sandf1972.23.4 56

Tsuchida, H., 1970. Prediction and Countermeasure against Liquefaction in Sand Deposits. Abstract of the Seminar of the Port and Harbour Research Institute, Ministry of Transport, Yokosuka, Japan, 3.1-3.33.

USGS, 2009. M 7.0 - Java, Indonesia. United States of Geological Survey, (https:// earthquake.usgs.gov/earthquakes/eventpage/usp000h152/executive).

Youd, T. L., Tinsley, J. C., Perkins, D. M., King, E. J., dan Preston, R. F., 1979. Liquefaction Potential Map of San Fernando Valley, California. Progress on Seismic Zonation in the San Francisco Bay Region US Geological Survey.

Zhao, J. X., Zhang, J., Asano, A., Ohno, Y., Oouchi, T., Takahashi, T., Ogawa, H., 
Analisis Potensi Likuefaksi di Daerah Cekungan Bandung Berdasarkan Data Standard Penetration Test (SPT)

Irikura, K., Thio, H. K., Somerville, P., Fukushima, Y., dan Fukushima, Y., 2006. Attenuation Relations of Strong Ground motion in Japan Using Site
Classification Based on Predominant Period. Bulletin of Seismological Society of America, 96(3), hal. 898-913. DOI: $10.1785 / 0120050122$ 